\title{
LOGISTIC AND ECONOMICAL PRECONDITIONS FOR PRODUCTION OF PELLETS FROM SAWDUST
}

\author{
Dariusz Kwaśniewski*
}

Department of Production Organization, Logistics and Applied Computer Science, University of Agriculture in Krakow, Poland, Dariusz.Kwasniewski@ur.krakow.pl ORCID: 0000-0002-1873-1456

*Corresponding author: e-mail: dariusz.kwasniewski@ur.krakow.pl

\begin{tabular}{|c|c|}
\hline ARTICLE INFO & ABSTRACT \\
\hline $\begin{array}{l}\text { Article history: } \\
\text { Received: May } 2019 \\
\text { Received in the revised form: } \\
\text { June } 2019 \\
\text { Accepted: June } 2019\end{array}$ & $\begin{array}{l}\text { The objective of the paper was to determine the costs of production and } \\
\text { production effectiveness of pellets made of sawdust and characteristics } \\
\text { of logistics of raw material carriage and distribution of pellets. The } \\
\text { scope of the paper covered the research carried out in the branch of } \\
\text { DREWEX company located in Chotelek town (Świętokrzyskie voi- }\end{array}$ \\
\hline $\begin{array}{l}\text { Key words: } \\
\text { pellets, } \\
\text { costs of production, } \\
\text { logistics of supplies, } \\
\text { economic effectiveness }\end{array}$ & $\begin{array}{l}\text { vodeship, Province of Busko Zdrój). Unit costs of pellets production } \\
\text { were: } 513.4 \text { PLN } \cdot \mathrm{t}^{-1} \text { for option } 1,423.3 \text { PLN } \cdot \mathrm{t}^{-1} \text { for option } 2 \text { and } 393.3 \\
\text { PLN } \cdot \mathrm{t}^{-1} \text { for option } 3 \text {. The most favourable was option } 3 \text { when the pellets } \\
\text { were produced on the technology line in the } 3 \text {-shift system day and } \\
\text { night. The average distance to seven cities from which sawdust was de- } \\
\text { livered was } 43.6 \mathrm{~km} \text { and the distance to which production was distrib- } \\
\text { uted to ten cities was on average } 105.5 \mathrm{~km} \text {. }\end{array}$ \\
\hline
\end{tabular}

\section{Introduction}

Biomass in the initial, unprocessed state, is a non-uniform, varied on account of physical properties. The process which improves its properties is pelleting, due to which fuel with uniform properties is formed under the influence of high pressure, sometimes of high temperature. The course of compaction of material is quite complex and the two most important groups of factors influence the expected parameters of the agglomerate. Material factors, such as a degree of fragmentation of raw material, its uniformity, occurrence of substances that facilitate combustion of fractions, as well as temperature and moisture in the moment of compaction constitute the first group. Structural and exploitation factors of the compacting device and treatment of the obtained product form the second group (Hejft, 2002; Hejft and Obidziński, 2006; Kraszkiewicz, 2016).

Raw materials for pellets production are obtained from: wood industry (any type of sawdust, wood shavings, chips, bark), from agricultural production (waste and post-production waste e.g. grain straw) and from fast growing plantations maintained for this purpose, i.e. energy willow, Virginia mallow and miscanthus (Frączek et al., 2010).

When products are produced from biomass, a distance between the production site and the final recipient is a significant aspect from the point of view of quality and profitability. It 
would be an ideal situation if raw material was used in the place of its production. However, in many cases it is impossible. Thus, the distance should the shortest as possible. Also storing generates excessive costs. To avoid those encumbrances, relevant raw material fluency should be ensured based on commercial contracts with recipients. A recipient in the signed contract with a raw material producer determines any requirements concerning the supplied product. Moreover, particular links of the logistic chain of obtaining and processing of agricultural biomass for energy purposes must also include requirements of the final recipient of the product. And final products of biomass from energy plants cultivation may be: wood chips, pellets, briquettes as well as bales of hay (Grzybek and Muzalewski, 2010).

Each type of biomass requires a different logistic process and triggers other problems related to harvesting, processing, storing or supply. In case of solid biomass processing other devices and barriers are encountered than in case of liquid biofuels or biogas production. These impediments result from diversity of raw materials processed into final products (Jasiulewicz and Janiszewska, 2012)

The most significant matter in pellet production is selection of raw material for production and ensuring its stock. Also, location of an establishment is important in relation to the source from which raw material is supplied and bought (Kwaśniewski et al., 2017). It should be also emphasised that the complexity of the technological line is related to a great power consumption for production of pellets and this causes that their price is often higher than the cost of raw material (Kachel-Jakubowska and Kraszkiewicz, 2014).

Costs of logistic processes as a sum of the of biomass storage costs, transport and the entire process of orders constitute a basis of the economic calculation in the assessment of the effectiveness of logistic operation of enterprises. Thus, a tool, scope and methods of their calculation constitute important tools in controlling the flow and storage of biomass (Kuboń, 2010).

A relevant logistic strategy of supply of raw material is an important aspect when planning production of compact fuels. Rational organization of transport and storing of raw material is a factor that preconditions production effectiveness. The article presents, inter alia, aspects related to the logistics of supply, including organization of supplies of raw material for production of sawdust pellet.

\section{Objective, scope, and methodology of work}

The aim of the paper was to determine the cost of production and production effectiveness of pellets made of sawdust and characteristics of logistics of raw material supply for production and distribution of pellets for the selected enterprise.

The scope of the paper covered the research carried in 2018 in DREWEX company located in Chotelek town (Świętokrzyskie voivodeship, Province of Busko Zdrój). A guided survey with the company owner enabled to collect information concerning the applied production technology and operation of the technological line for pellet production.

Moreover, information on organization of production were obtained:

- sources of purchase and frequency of purchase of raw material for production of pellets,

- number of shifts and working hours in a day,

- number of employees which work in the production line,

- organization of work at each stage of line operation, 
Logistic and economical preconditions...

- organization of raw material supply for production (distances from the place of purchase, duration of a journey),

- distribution of pellets (manner of packing a product, distance to the place of sale, duration of a journey).

A guided survey also enables collection of data indispensable to determine elements of the total costs of production of pellets $\left(\mathrm{K}_{\mathrm{prod}}\right)$. Elements include costs of purchase of raw material (sawdust) $\left(\mathrm{K}_{\mathrm{s}}\right)$, costs of internal transport $\left(\mathrm{K}_{\mathrm{t}}\right)$, amortization costs $\left(\mathrm{K}_{\mathrm{a}}\right)$, costs of renovation and maintenance $\left(\mathrm{K}_{\mathrm{r}}\right)$, costs of electric energy $\left(\mathrm{K}_{\mathrm{e}}\right)$, costs of remuneration of employees $\left(\mathrm{K}_{\mathrm{w}}\right)$

$$
\mathrm{K}_{\text {prod }}=\mathrm{K}_{\mathrm{s}}+\mathrm{K}_{\mathrm{t}}+\mathrm{K}_{\mathrm{a}}+\mathrm{K}_{\mathrm{r}}+\mathrm{K}_{\mathrm{e}}+\mathrm{K}_{\mathrm{w}}
$$

The following assumptions resulting from the activity of the enterprise were included in the calculation of production costs of pellets:

- production line performance - $600 \mathrm{~kg} \cdot \mathrm{h}^{-1}$

- use of sawdust per a tonne of produced pellets $-7 \mathrm{st} \cdot \mathrm{t}^{-1}$ of pellets, (stere)

- price of sawdust - on average $18 \mathrm{PLN} \cdot \mathrm{st}^{-1}$

- price of purchase of raw material (sawdust) together with carriage: on average $126 \mathrm{PLN} \cdot \mathrm{t}^{-1}$,

- price of Atlas AR65 loader - 58700 PLN,

- fuel consumption by Atlas AR65 $-6 \mathrm{dm}^{3} \cdot \mathrm{h}^{-1}$,

- fuel price: $4,50 \mathrm{PLN} \cdot \mathrm{dm}^{-3}$,

- technological line with full equipment: 1100000 PLN,

- electric power installed: $110 \mathrm{~kW}$,

- price of electrical energy: $0.8 \mathrm{PLN} \cdot \mathrm{kWh}^{-1}$,

- costs of drying of sawdust: $15 \mathrm{PLN} \cdot \mathrm{t}^{-1}$ of sawdust (acc. to information provided by the company's owner),

- costs of renovations and maintenance of machines and devices comprising a technological line; $54000 \mathrm{PLN} \cdot \mathrm{rok}^{-1}$ (including a double replacement of a head in a pelleting machine).

- Additional assumptions for calculations were accepted:

- amortization of the loader Atlas AR65 at the level of $18 \%$ in the year's scale,

- loading of the loader Atlas AR65 at the level of 70\%,

- amortization of the technological line at the level of $20 \%$ in the year's scale,

- loading of devices that comprise the technological line at the level of $80 \%$,

- remuneration for employees: $13 \mathrm{PLN} \cdot \mathrm{h}^{-1}$.

The production costs of pellets were determined in the one year's scale and analysis included three options:

- option 1 - one-shift work, line performance $600 \mathrm{~kg} \cdot \mathrm{h}^{-1}$, annual pellet production approx. 1584 tones,

- option 2 - two-shift work, line performance $600 \mathrm{~kg} \cdot \mathrm{h}^{-1}$, annual pellet production approx. 3168 tones,

- option 3 - three-shift work, line performance $600 \mathrm{~kg} \cdot \mathrm{h}^{-1}$, annual pellet production approx. 4752 tones, 
Dariusz Kwaśniewski

The paper presents economic effectiveness of production of sawdust pellet as a relation of a unit price of pellets sale $\left(\mathrm{PLN} \cdot \mathrm{t}^{-1}\right)$ to the unit costs of pellet production $\left(\mathrm{PLN} \cdot \mathrm{t}^{-1}\right)$.

For calculation of effectiveness (based on the information from the company's owner) four prices of sale of pellets: $600,670,700$ and $750 \mathrm{PLN} \cdot \mathrm{t}^{-1}$ were applied.

\section{Research results}

Purchase of raw material in the form of sawdust for production of biofuel took place for the entire year in the amount that enabled production without stoppages. Raw material was purchased in southern Poland from seven cities in the distance from the registered office of the enterprise from $2.3 \mathrm{~km}$ (A7) to $86.2 \mathrm{~km}$ (A5) (table 1). The average distance from which sawdust was supplied was $43.6 \mathrm{~km}$. Journey to particular cities in majority of cases did not exceed 1 hour and on average was $44.7 \mathrm{~min}$.

Table 1.

Cities from which sawdust for production of pellets was delivered

\begin{tabular}{llcc}
\hline Item & City & $\begin{array}{c}\text { Distance from } \\
\text { Chotelek }\end{array}$ & $\begin{array}{c}\text { Predicted duration } \\
\text { of a journey }\end{array}$ \\
\cline { 2 - 4 } & & $(\mathrm{km})$ & $(\mathrm{min})$ \\
\hline 1 & A1 - Jędrzejów & 41.3 & 45.0 \\
2 & A2 - Małogoszcz & 63.3 & 63.0 \\
3 & A3 - Michałów & 26.7 & 30.0 \\
4 & A4 - Radkowice & 49.2 & 47.0 \\
5 & A5 - Starachowice & 86.2 & 86.0 \\
6 & A6 - Szydłów & 36.5 & 39.0 \\
7 & A7 - Wolica near Busko & 2.3 & 3.0 \\
\hline & Minimum & 2.3 & 3.0 \\
& Average & 43.6 & 44.7 \\
& Maximum & 86.2 & 86.0 \\
\hline
\end{tabular}

Sawdust was stored under the roof on a site located directly at the production line. This manner of storing additionally influenced the natural process of drying the raw material. A distance to which raw material was transported from the storage place to the production line was approximately $250 \mathrm{~m}$. Internal transport of raw material took place with the use of ATLAS AR 65 loader.

The following stages may be distinguished in the straw pellet production technology applied by EKO-BIOMASA company:

- storage of raw material (station roofs),

- internal transport of sawdust (ATLAS loader),

- sorting and cleaning of raw material (sawdust from sawmills), 
Logistic and economical preconditions...

- drying in a drum dryer,

- additional evaporation,

- pelleting

- cooling (temperature below $40 \mathrm{C}$ degrees),

- weighting and packing (bags $15 \mathrm{~kg}$, big bags $1000 \mathrm{~kg}$ ).

- The following machines and devices are installed in the production line:

- a bin with sorting of bigger wastes from sawdust on the roller conveyor,

- screw feeder,

- a boiler for firing of a drum dryer,

- drum dryer PROEKO (efficiency $1000 \mathrm{~kg}$ of sawdust per hour),

- a set of inlet and outlet channels from a dryer,

- a vent and container for dry sawdust,

- cooler,

- granulator Mechanika Nawrocki,

- a welding machine, weighting and packing machine,

- a control cabinet with a central computer and control boxes at single devices i.e. dryer, granulator, etc.

The entire technological line was automatically controlled with the use of control cabinets with a central computer for operation of which 1 employee was needed.

Sawdust with moisture of ca. 30\% was transported to a charging hopper with ATLAS AR65 loader and then to a drum dryer with a feeder. The dryer was heated with a furnace fired with wood wastes where temperature was up to $700^{\circ} \mathrm{C}$. Then the screw conveyor moved raw material to further stages of production. In the process of pellet production in the investigated company, an additional process of material vaporization with the use of an evaporator was used. After the vapour was introduced before a matrix, sawdust was more humid. This process caused that better-quality pellets were obtained. It was more vitreous and pressed. After the sawdust got through a granulator, the final effect was in the form of produced pellet with a diameter of $6 \mathrm{~mm}$. Their properties include calorific value $18.8 \mathrm{MJ} \cdot \mathrm{kg}^{-1}$ content of ash $-\max 0.6 \%$, moisture $-\max 6 \%$. Table 2 includes description of production of pellets from sawdust for investigated variants.

Table 2 .

Pellet production costs for the investigated options

\begin{tabular}{llcccc}
\hline \multirow{2}{*}{ Item } & Specification & \multirow{2}{*}{ Unit } & \multicolumn{3}{c}{ Option } \\
\cline { 3 - 5 } & & $\left(\mathrm{kg} \cdot \mathrm{h}^{-1}\right)$ & 600 & 600 & 600 \\
\hline 1. & Performance of production line & $(-)$ & 1 & 2 & 3 \\
2. & Number of changes & $(\mathrm{h})$ & 8 & 16 & 24 \\
3. & Hours of operation in a day & $9(\mathrm{item})$ & 1 & 1 & 1 \\
4. & Number of pelleting machines & $($ persons $)$ & 4 & 8 & 12 \\
5. & Number of employees & $(\mathrm{kW})$ & 110 & 110 & 110 \\
6. & Power of installation & $\left(\mathrm{t} \cdot \mathrm{days}^{-1}\right)$ & 4.8 & 9.6 & 14.4 \\
& & $\left(\mathrm{t} \cdot \mathrm{month}^{-1}\right)$ & 144 & 288 & 432 \\
7. & Size of production of pellets (average) & $\left(\mathrm{t} \cdot \mathrm{year}^{-1}\right)$ & 1584 & 3168 & 4752 \\
\hline
\end{tabular}


Elements of the production costs of pellets and total costs of production based on the purchased raw material in the form of sawdust were presented in table 3. On the other hand, figure 1 presents the cost structure for the analysed options. The total costs of production of pellets were respectively: for option $1-513.4 \mathrm{PLN} \cdot \mathrm{t}^{-1}$, for option $2-423.3 \mathrm{PLN} \cdot \mathrm{t}^{-1}$, for option 3 - 393.3 PLN $\cdot \mathrm{t}^{-1}$. To compare, the costs of pellet production from grain straw in another establishment which processes biomass, located on the area of Southern Poland were 380 PLN $\cdot \mathrm{t}^{-1}$ (Szul, 2013). In other study (Kwaśniewski and Kuboń, 2016) the costs of pellets from grain straw were from 278.9 to $310.2 \mathrm{PLN} \cdot \mathrm{t}^{-1}$. Whereas, in the paper by Kraszkiewicz et al., (2015) the average costs of production of pellets from waste plant biomass (wheat straw, rye straw, triticale straw, barley straw and hay) were $269.85 \mathrm{PLN} \cdot \mathrm{t}^{-1}$, out of which the highest were incurred on the purchase of raw material $(44.5 \%)$. The second place in the structure $(15.5 \%)$ was taken by expenditures on electric energy.

In the analysed costs of pellets production for option 2 and 3 the highest participation in the cost structure (respectively $29.8 \%$ and $32.0 \%$ ) were in case of the costs of purchase of sawdust (126.0 PLN $\left.\cdot \mathrm{t}^{-1}\right)$. Contrary, for option 1 where amortisation of devices was the most expensive and the costs were $138.9 \mathrm{PLN} \cdot \mathrm{t}^{-1}(27.1 \%$ in the structure), which resulted from low efficiency of the use of a technological line (production in this option lasts only 8 hours per a day). For options 2 and 3 amortisation of devices was ca. two and three times lower (69.4 and 46.3 PLN $\cdot \mathrm{t}^{-1}$ ) and in the structure it is 16.4 and $11.8 \%$ (fig. 1). Another important expense which comprised the total cost of production of pellets was the cost related to consumption of electric energy. It was $117.3 \mathrm{PLN} \cdot \mathrm{t}^{-1}$ and the percentage participation in the cost structure increased (from $22.9 \%$ in option 1 to $29.8 \%$ in option 3 ) along with the number of hours per day during which the technological lines operated. It should be mentioned that during the third shift a night tariff and the electric energy price was not included since in the period when studies were performed, it did not function.

Table 3.

Pellet production costs for the investigated options

\begin{tabular}{|c|c|c|c|c|}
\hline \multirow[b]{2}{*}{ Item } & \multirow[b]{2}{*}{ Specification } & \multicolumn{3}{|c|}{ Option } \\
\hline & & 1 & $\begin{array}{c}2 \\
\left(\mathrm{PLN} \cdot \mathrm{t}^{-1}\right)\end{array}$ & 3 \\
\hline 1. & Costs of purchase of sawdust & 126.0 & 126.0 & 126.0 \\
\hline 2. & Costs of internal transport & 38.2 & 34.8 & 33.7 \\
\hline 3. & Costs of drying & 15.0 & 15.0 & 15.0 \\
\hline 4. & Amortisation of devices & 138.9 & 69.4 & 46.3 \\
\hline 5. & Renovations and maintenance & 34.7 & 17.4 & 11.6 \\
\hline 6. & Electrical energy & 117.3 & 117.3 & 117.3 \\
\hline \multirow[t]{2}{*}{7.} & Remuneration of employees & 43.3 & 43.3 & 43.3 \\
\hline & Costs of pellets production & 513.4 & 423.3 & 393.3 \\
\hline
\end{tabular}

In the assessed costs of production, the lowest participation in the structure (2.9 to $3.8 \%$ ) was characteristic for the costs of drying which were $15 \mathrm{PLN} \cdot \mathrm{t}^{-1}$. One of the lowest costs (for all analysed options) were incurred for renovations and maintenance of machines and devices 
Logistic and economical preconditions...

which comprise the technological line and their participation in the structure was from $2.9 \%$ for option 3 to $6.8 \%$ for option 1). Costs incurred for internal transport were included to small expenses and the participation in the cost structure was within $8.6 \%$ (option 3 ) to $7.4 \%$ (option 1).

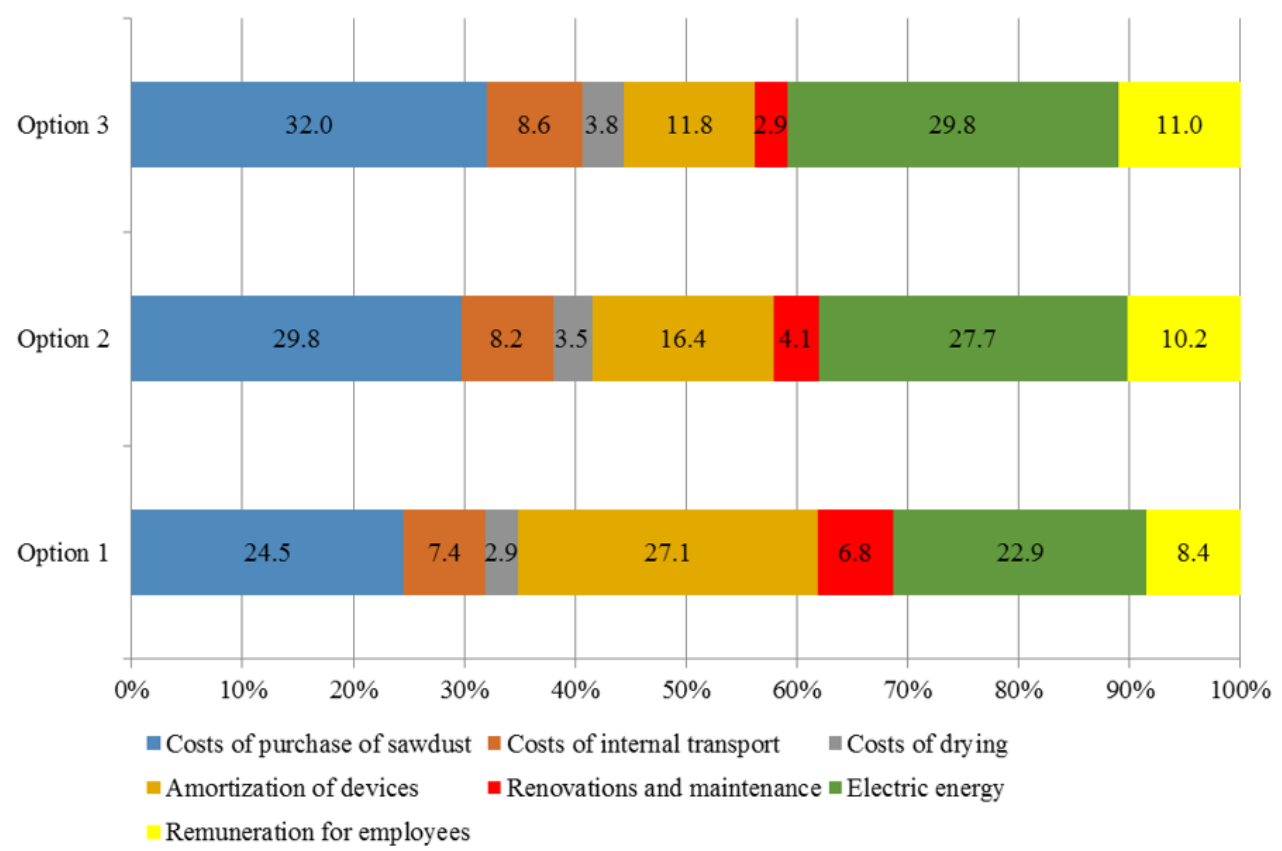

Figure 1. Structure of pellet production costs for assessed options of production

Economic effectiveness indicators of sawdust pellet production for the investigated options were presented in figure 2. Summing up the obtained results, it should be concluded that for each option of production and for assumed prices of sale, a profitability threshold was exceeded - the economic effectiveness indicator was higher than unities. It should be emphasised that option 1 (one-shift work) was the least profitable. The most profitable solution for pellets production is option 3 - at the three-shift system, where the economic effectiveness indicators of pellets production was from 1.5 to 1.9. It is related to the most efficient use of the technological line (the lowest costs of unit amortisation).

Companies, educational centres, and individuals were recipients of pellets produced in the analysed enterprise. Pellets were transported to the distance of $182 \mathrm{~km}$ (B6) to $216 \mathrm{~km}$ (B7) from the registered office of a company. An average distance was $105.5 \mathrm{~km}$. The journey to clients was considerably longer from the time of supply of raw material for production. An average journey time was $1 \mathrm{~h} 39 \mathrm{~min}$ in one direction. Table 4 presents cities where the 
Dariusz Kwaśniewski

produced pellets were delivered and sold. Transport of raw material for production and pellets took place by trucks Man L2000 8.163 LC with an admissible loading of 3.5t and Renault 450 Dxi with an admissible loading of $28 \mathrm{t}$ which are owned by the enterprise.

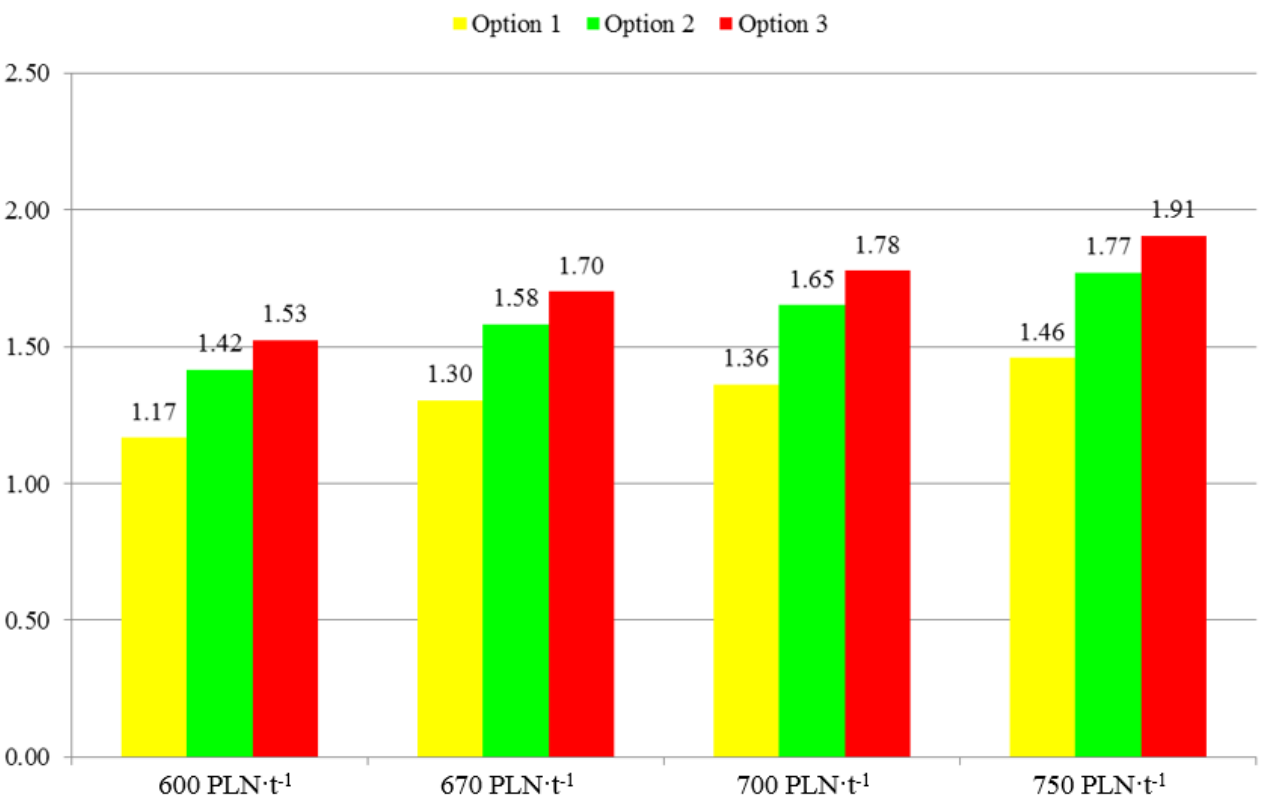

Figure 2. Economic effectiveness of pellets production from sawdust

Table 4

Cities to which pellets were delivered and sold

\begin{tabular}{llcc}
\hline \multirow{2}{*}{ Item } & City & $\begin{array}{c}\text { Distance from } \\
\text { Chotelek }\end{array}$ & $\begin{array}{c}\text { Predicted duration } \\
\text { of a journey }\end{array}$ \\
\cline { 3 - 4 } & & $(\mathrm{km})$ & $(\mathrm{min})$ \\
\hline 1 & B1 - Cedzyna near Kielce & 55.5 & 57 \\
2 & B2 - Jawornik & 129.0 & 103 \\
3 & B3 - Krempna near Jasło & 155.0 & 156 \\
4 & B4 - Ostrowiec Świętokrzyski & 92.9 & 87 \\
5 & B5 - Pajęczno & 170 & 163 \\
6 & B6 - Pińczów & 18.2 & 21 \\
7 & B7 - Sędziejowice near Lódź & 216.0 & 198 \\
8 & B8 - Skarżysko-Kamienna & 87.6 & 78 \\
9 & B9 - Starachowice & 86.2 & 86 \\
10 & B10 - Staszów & 44.1 & 42 \\
\hline & Minimum & 18.2 & 21 \\
& Average & 105.5 & 99 \\
& Maximum & 216.0 & 198 \\
\hline
\end{tabular}


Logistic and economical preconditions...

Information concerning packing of pellets to $15 \mathrm{~kg}$ bags:

- Industrial pallets $1200 \times 1000 \mathrm{~mm}$ were used for packing the pellets,

- Rough foil or a cartoon spacer was placed on a pallet,

- A full load of a truck consisted of 23 pallets (23 pallets x 70 bags),

- $15 \mathrm{~kg}$ bags were placed in layers 5 item each to obtain binding,

- On each pallet 14 layers of bags, namely 70 bags, were placed.

- Each pallet was wrapped around in foil (at least with layers),

- During the 2 and 3-shift production, pallets were stored one on another (no more than 2 layers), then spacers/ wooden tops were used.

$1050 \mathrm{~kg}$ of pellets could have been placed on a pallet.

On the other hand, big bags were directly packed during production, namely, the produced pellets with an outlet channel were transferred to big bags placed on pallets $1000 \mathrm{~kg}$ each.

\section{Conclusions}

- Purchase of raw material in the form of sawdust was carried out for the entire year from seven sawmills located on the territory of southern Poland. The average distance from which sawdust was supplied was $43.6 \mathrm{~km}$. Journey to sawmills in majority of cases did not exceed 1 hour and on average was $44.7 \mathrm{~min}$.

- Pellets were purchased by companies, educational centres and by individuals. A distribution distance to 10 cities was on average $105.5 \mathrm{~km}$ and the journey was on average 1 hour and 39 minutes in one direction. Pellets were delivered in $15 \mathrm{~kg}$-bags in $1000 \mathrm{~kg}$-big bags.

- The total costs of production of pellets from sawdust in the investigated company were within $393.3 \mathrm{PLN} \cdot \mathrm{t}^{-1}$ for option 3 (3-shift work) to $513.4 \mathrm{PLN} \cdot \mathrm{t}^{-1}$ for option 1 (one-shift work).

- Option 1 of production (one-shift work) was the least profitable (economic effectiveness indicator was from 1.2 to 1.5 ). The best solution for the company would be the use of a three-shift system (option 3) since the production costs were the lowest and the technological line was effectively used (which lowered the costs of amortisation of devices). The assessed indicator in relation to the assumed prices of sale of pellets was then within 1.5 to 1.9 .

\section{References}

Frączek, J. (red.). (2010). Optymalizacja procesu produkcji paliw kompaktowanych wytwarzanych z roślin energetycznych. Wyd. Polskie Towarzystwo Inżynierii Rolniczej. Kraków. ISBN 978-83930818-0-6.

Grzybek, A., Muzalewski, A. (2010). Logistyka przetwarzania biomasy na biopaliwa. Czysta energia, 2, 17-19.

Heift, R. (2002). Ciśnieniowa aglomeracja materiałów roślinnych. Wyd. ITE, Radom. ISBN 837204251-9.

Hejft, R., Obidziński, S. (2006). Produkcja granulatu i brykietów w aspekcie cech jakościowych. Czysta Energia, 6, 23-27. 
Jasiulewicz, M., Janiszewska, D. A. (2012). Problem logistyki agro-biomasy do celów energetycznych. Logistyka 4, 981-987.

Kachel-Jakubowska, M., Kraszkiewicz, A. (2014). Zrównoważony rozwój rynku biomasy. W: Szpryngiel M. (red). Zrównoważone wykorzystanie surowców roślinnych i przemysłowych do produkcji peletów. Lublin. ISBN 978-83-63761-39-4.

Kraszkiewicz, A., Lorencowicz, E., Kachel-Jakubowska, M. (2015). Koszty produkcji peletów z biomasy roślinnej pochodzenia rolniczego. http://www.ptzp.org.pl/files/konferencje/kzz/artyk_pdf_2015/T1/t1_0470.pdf(Dostęp w dniu 20.06.2019 r).

Kraszkiewicz, A. (2016). Wptyw właściwości fizycznych i chemicznych biopaliw pochodzenia roślinnego na emisję produktów spalania i efektywność energetyczna. Wyd. Uniwersytetu Przyrodniczego. Lublin. Rozprawy Naukowe. Zeszyt 386. ISSN 1899-2374.

Kuboń, M. (2010). Transport i logistyka dostaw biomasy. W: Frączek J. (red). Produkcja biomasy na cele energetyczne. Wyd. PTIR. Kraków. ISBN 978-83-917053-8-4. S. 167-196.

Kwaśniewski, D., Kuboń, M. (2016). Economic effectiveness of straw pellets production. Agricultural Engineering 4, 147-155.

Kwaśniewski, D., Kuboń, M., Malaga-Toboła, U. (2017). Logistyka dostaw a koszty produkcji paliw kompaktowych. W: Aktualne problemy logistyki. Tom 1. Dzieniszewski G., Kuboń M. (red). Przemyśl. ISBN 978-83-60184-96-7.

Szul, T. (2013). Ocena opłacalności produkcji peletów ze słomy. Technika Rolnicza Ogrodnicza Leśna 2, 17-19.

\section{UWARUNKOWANIA LOGISTYCZNO-EKONOMICZNE PRODUKCJI PELETÓW Z TROCIN}

Streszczenie. Celem pracy było określenie kosztów produkcji i efektywności produkcji peletów z trocin drzewnych oraz charakterystyka logistyki dostaw surowca do produkcji oraz dystrybucja peletów. Zakresem pracy objęto badania przeprowadzone w oddziale firmy DREWEX, który znajduje się w miejscowości Chotelek (województwo świętokrzyskie, powiat buski). Jednostkowe koszty produkcji peletów wyniosły: 513,4 PLN $\cdot t^{-1}$ dla wariantu 1, 423,3 PLN $\cdot t^{-1}$ dla wariantu 2 oraz 393,3 PLN $\cdot t^{-1} \mathrm{dla}$ wariantu 3. Najbardziej korzystnym był wariant 3, gdy produkcja peletów prowadzona była na linii technologicznej w systemie 3 zmianowym przez całą dobę. Średnia odległość do siedmiu miejscowości z których dostarczane były trociny wyniosła $43,6 \mathrm{~km}$, a odległość dystrybucji produktu do dziesięciu miejscowości to średnio $105,5 \mathrm{~km}$.

Słowa kluczowe: pelety, koszty produkcji, logistyka dostaw, efektywność ekonomiczna 